\title{
Analysis, About the Origin, Development and Formation of the Notion of Ownership, its Review in Relation to the Economic Developments
}

\author{
YIlka Rupa \\ "Luigj GurakuqI" University Shkoder Albania, Faculty of Law
}

Doi:10.5901/ajis.2015.v4n2s1p201

\begin{abstract}
This article addresses the progress and development of the notion of ownership in relation to the economic developments. The ownership relations are as dynamic as the economic and commercial developments are. For this reason different authors have $d w e l t$ upon and treated the characteristics and nuances that this institution adopts in relation to other social relationships in various stages of development. This paper analyzes different opinions about the term and the notion of ownership as well as explaining some of the denominations it has had in the Albanian legislation.
\end{abstract}

Keywords: Ownership, definition, possession, subjective right, owner, terminology

\section{Analysis of the Ownership in Relation to the Development of the Relations of Production}

Numerous studies in the field of law and jurisprudence are focused on the right of ownership, as the most important institution of civil law. Today the specialists in civil law admit that ownership constitutes the essence of civil legal relations from where other relationships that belong to different branches of law arise and develop. In essence, it is a social relationship, namely a relationship between persons with respect to self-owned things, whether these are gifts of nature or products of human labor. Ownership occupies a central place in every legal order. It determines the content of all other legal institutions. Despite the historical periods of their development, the legal systems have paid a special attention to the regulation of the property legal relations and other rights closely related to them. In a historical overview of the development of property relations, it is noted that the legal arrangements of the institution of ownership are conditioned by appropriate forms of development of the economic relations of production. In every social order the legal regulation of ownership is done basing on the characteristics of the general legal and political regulation of that order and for this reason ownership is not presented as a unique and unchanged form, but it appears differently depending on the features characterizing the social orders. At its core, ownership appears as a legal and particularly real legal category, where the power of the owner over the thing, has the characteristics of an absolute inviolable and unlimited right. We note this definition in all economic and social formations, ranging from the most primitive to the most developed ones, namely in contemporary definitions given to ownership.

Development of ownership shall be seen closely linked with the development of the means of production. Even the character of social - economic relations themselves, known to date in the history of human society, is determined by the fact who is the owner of the basic means of production. The dominant forms of ownership in each society, in every legal order, are determined based on who owns the means of production. The development of the relations of production is accompanied by the development of property relations. In the earliest stages of the development of property relations there could be no talk about written and codified legal definitions; despite this, it can be spoken about relationships in-fact that depending on the long time of their existence and their uniform regulation in accordance with protected interests, assume the traits of the stable and decisive relationships for the development of all other relations having in their center the most indispensable means for realizing the property rights.

With the change and development of the relations of production, the legal superstructure changes and develops. It affects to a significant extent and borders the change and development of the relations of production. Therefore the institution of ownership should not be viewed and analyzed separately from the economic changes, but as the clearest expression of these changes. Property is the most important institution in the human society and has a double economic and legal significance. Ownership as an economic notion implies appropriation (exploitation) of material goods, but in legal terms this means a collection of legal norms that regulate this exploitation. These legal norms through the sanction, as their most indispensable element, regulate the property relations, constitute the right of ownership in the objective meaning. The property in itself is built on the basis of a relation that is established between its holder (owner) and the 
thing that is the subject of property.

This relation enjoys legal protection from the moment of its inception and consists in the right of the owner to dispose over everything related to the property. This means that the owner has a special, concrete prerogative, the subjective right that belongs only to him and enables the realization and protection of all the powers he has over the property. The subjective right consists of two possibilities: the possibility that the entity performs certain actions, allowed by the civil legal norms, as well as the possibility to demand from the obligated subject to conduct or not conduct certain actions in his favor. The legal power of ownership is governed by the legal norms set by the state, henceforth ownership is not only a social relationship of an economic character, but is a known legal relationship, regulated and protected by law. Ownership being raised to the legal relationship becomes the right of ownership. In classical Roman law ownership is defined as full power over the property (dominium propretias). The owner enjoyed full power over the property and this power consisted of three types the powers: ius utendi, fruendi et aputendi. By ius utendi it is understood the right of possession and use of the property by the owner, by ius abutendi it is implied the right of alienation or of creation on the property of another real right to the benefit of a third person or the right of full destruction or disposal of the property. On the other hand the right of ownership was guaranteed by the interventions of other persons on the thing, but the power of the owner over the property was not completely unlimited. In the Romans we do not find anywhere that the right of private ownership is mystified, as happened to the Germans. The right of private ownership is ius utendi et abutendi, the right to dispose arbitrarily a thing and this was the pedestal, on which was set up the right of ownership to a certain degree of overall development of property relations. Roman Law introduced various restrictions on the power of the owner, prohibiting misuse of subjective right in general (male enim iurenostro uti non debemus), the owner does not have to abuse his own right.

The private property relations and property legal institutions have existed since in the ancient legal systems. But an accurate and correct study to the ownership notion is found in legal systems, which are characterized by a high degree of development of the private property. In them ownership has gained its legal and historic character. Historically, the right of ownership was born with the division of society into classes. Then, in the course of development of the human society, in various social economic formations, the right of ownership becomes the central legal institution of any legal order, under which runs the legal character of all other institutions. In Albania the property legal relations generally are conditioned by the political and social economic developments in the country. They are conditioned by the political and legal order that has governed the country. The relations of ownership in Albania gained a modern conception based on consolidated legal and democratic principles only during the Albanian Monarchy. This period may be marked as complete reversal of an antiquated legal system and the beginning of a new era in the conception, development and implementation of the ownership relations.

\section{The Notion of Ownership and Definitions Provided Around It}

The definitions on the right of ownership have aimed to include important elements that characterize this legal institution. This is evidenced not only in the definitions provided by the legal doctrine, but also in legal formulations of various legislations. These definitions are intended to reflect the most essential elements of the right of ownership, mainly the powers of the owner, or the rights the owner has over his thing. The definitions made on the right of ownership pose many changes depending on the diversity the different legal systems represent and according to the historical periods when these definitions are made.

Meanwhile the definitions made on ownership generally adhere to the Roman concept formulation of ownership. This is evident in all modern legislation, which base the provisions made on the right of ownership on the concept provided in the Roman law. The Romans were the first to define the right of ownership; this is because the economic and property relations in this period appear more consolidated than ever before. The higher the general development of private property relations, the more differentiated, more crystallized and formed will be the notion of ownership and property rights. In Roman law, for the first time the right of ownership rises to levels of absoluteness and exclusivity enabling the property holders' full absolute and exclusive power over the thing. They relied on the Roman definition of property and elaborated the legal definitions of ownership in the modern civil codes, which defined the right of ownership as an absolute right to act against all and all are bound by omission. All these codes determine the right of ownership as ius utendi, ius fruendi and ius abutendi (right of possession, enjoyment and disposition of the property) setting out the three traditional powers of the owner. The contemporary definitions of ownership have tried to categorize it as a more complete and exclusive judicial power of the owner to a thing.

The French Civil Code Article 544 provides this definition of ownership: 
"Ownership is the right to enjoy and dispose in the most absolute terms (ie without restrictions), except those prohibited by law or regulation".

This definition had a clear impact on the ownership principles outlined in the Declaration of the Rights of Man and Citizen of 1789, which considered the ownership and freedom as inseparable from man. The definition of property as an absolute right aimed at discharging the owners from all feudal burdens and limitations and was in full harmony with the modern viewpoint that in its notion, ownership is inseparable from man. The definition made by the French Civil Code became the inspiration for almost all the definitions to come of the legislation made on the right of ownership

The German Civil Code Article 903 gives this definition on ownership:

"The owner of the thing can behave and dispose it as per his wish and exclude others from any interference insofar as the law or the rights of third parties do not prohibit such a thing ".

In this code dating later than the French Code absoluteness is waived laying the emphasis also on the restrictions to ownership. These restrictions can be done not only by the state through laws, but the owner can not carry out any action that violates the rights of a third person, or limits third parties from exercising their rights. The definition provided by the German Civil Code represents fully two important elements of the concept of ownership. It reflects the fundamental elements that make up the entire contents of the right of ownership: on one side the positive element under which the owner has absolute and total power over the thing, which authorizes him to exercise on the thing any right that can be thought of, as long as he is not prohibited by the law and not prevented from the competition of third party rights, on the other hand the negative element, whereby the holder of the property may exclude any third party from interfering in the enjoyment of his thing. The Italian Civil Code in its Article 832 provides the following definition of ownership: "The owner has the right to enjoy and dispose of things fully, exclusively, within the limits and in respect to the legal obligations contained in the juridical rule."

The development of the content to the right of ownership, as defined by Article 832 of the Italian Civil Code, depends on the expansion and the quality of the property boundaries and obligations imposed on the owner by the legislator. In this definition, the owner has exclusive power over the thing and the limitations on the exercise of his right are imposed in all the cases in respect of the legal obligations contained in the juridical order. The exclusivity of the right of ownership lies on the possibility that the law recognizes the owner to exclude anyone from enjoying and disposing it. This character of the property is one that defines the phenomenon: the relationship between man and the object is transformed into a relationship between people, the claim of individuals to use the property to the exclusion of others. This character of ownership is the one that defines the phenomenon: the relationship between man and the thing is transformed into a relationship between people, in the claim of individuals to use the property by excluding the others. We quoted the above codes because the whole civil legal and in particular the property system in the Albanian Monarchy was built based on the principels they affirmed on ownership and other real rights.

The definitions made on ownership by the most important legal acts of this period are a clear expression of the conception and the treatment of the basic law institutions, according to the spirit that characterizes the above codes.

The period of the Albanian Monarchy was a new milestone on the difficult path of the consolidation of the Albanian state. Characteristic of this period is the preparation of a western legislation and of the institutions responsible for its implementation. The civil legal framework marks its peak with the adoption of the Civil Code. The first legal definitions of the legal institution of ownership in Albania belong exactly to this period and this code. Article 794 provides a definition similar to that given in the French Civil Code. It reads that: "Possession is the right to enjoy and dispose of things without any limitation, beyond those defined by law or regulation."

As noted the definition contained in Article 794 derives from the French Civil Code, but the term "ownership" is replaced with the term "possession". In the legal literature of the time there were objections about the definition of possession. From one side it is lacking, as it says more than it should, on the other. This definition is considered flawed because it does not express and leaves in the dark one of the most essential elements of the possession: the owner's negative and exclusion power, the owner's authority to exclude any person from enjoyment of the property. It says more than enough, because the right of enjoyment and the disposition in reality are not absolute, but rather subject to many restrictions, as mentioned in Article 794. According to Benussi, the definition in question is not complete from another point of view, because it mentions the possession restrictions stemming from the law and regulations leaving in silence other restrictions that may stem from the competition of the other's right despite the legal restrictions. The ownership laws that were adopted in Albania after World War II define the ownership by trying to include in the definition the most 
essential elements of its enjoyment, disposition and possession.

The Civil Code 1994, Article 149 gives this definition of ownership: "Ownership is the right to enjoy and dispose of things freely, within the limits prescribed by law". This wording is almost identical to that of the Civil Code of 1929. The definition made includes two important powers of the owner, enjoyment and disposition, while possession and definition for it is made in specific provisions of the Civil Code. This does not mean that the owner does not have such a right. Possession may also be as a separate right, which can be a person other than the owner. Proprietary rights over the property are numerous and vast, so they may not be included in a single definition. The Civil Code deals separately with the power-in-fact over the thing, or possession, but separate articles make the legal regulation of those rights owned by the property owner due to the existence of his thing. The rights stemming from the owner's absolute power over the thing are related to the ownership on its civil and natural fruits. The ownership of its constituent parts belongs to the owner of the thing.

\subsection{The Albanian legal terminology on ownership.}

In the Albanian legal terminology, the terms "property", "ownership", "owner" are mainly used for the determination of ownership relations. These terms have been part of all definitions that are made by the law and legal doctrine, excluding the period of monarchy. The Albanian Civil Code of 1929 referred to the term "possession" to express the right of property ownership and propriety legal relations. Even the literature of the time uses the term, when commenting on property relations and the term "possessor", when speaking of the owner.

This term corresponds to the Roman term "dominium", but can also contain in itself even possession as a powerin-fact. On the other hand, it does not correspond either to the terminology used in its sister-like codes. The French Law formulated a legal-technical term for ownership, "propriete" , while in the German legal terminology, the term "eigentum" was used. Both terms imply the term "ownership". Possession as a legal term will not be seen any more in any of the descriptions to be provided by the Albanian jurisprudence in continuation. There were opinions that this was not elaborated as an abstract legal technical term to express the concept of ownership. Despite this, the definition given to ownership in the Civil Code of 1929 has served as a model for later definitions given to ownership. Based on these, we can say that the definitions on ownership cannot be comprehensive and thorough so as to reflect all the elements of the case to be defined. The content of the right of ownership as a subjective right can be analyzed through the three powers of the owner: enjoyment, possession and disposition. These are the proprietary powers known by law and as a whole, make up the content of the right of ownership.

\section{Conclusions}

The right of ownership is a social relationship between people regarding the thing; so being it has a high legal arrangement and constitutes the essence of other civil legal relations.

It appears as a complex institution that cannot have a narrow approach; its features, characteristics, elements must be viewed in relation to other social economic developments.

Ownership is the clearest expression of the development of the economic relations and being such, it is presented to us with a twofold economic and legal understanding.

The juridical power of ownership is governed by the legal norms established by the state, so it is a legal relationship regulated and protected by law. The owner's guarantee to the interventions of other persons on the property, except in cases specified by law, is expressed in this sense.

For the first time in the Albanian legislation, the right of ownership witnessed an adjustment in the era of modern Albanian Monarchy. This period can be viewed as a complete overturn of an antiquated legal system and the beginning of a new era in the conception, development and implementation of ownership relations.

Roman law launched a reforming step in the definition made to the right of ownership. It enhanced the right of ownership to the levels of absoluteness and exclusivity, giving its holder the full power over the thing.

Modern definitions regarding the ownership have tried to be complete in the integration of all the elements that constitute it.

The Albanian legal terminology of ownership is mainly based on the terms "property", "ownership", "owner" and there is no difference from what is used in the continental right. 


\section{References}

Aliu, Abdulla. The Real Right. Prishtina 2006.

Benussi, Baltazar. Objects, their Possession and Modifications. Book III of Civil Code, Publication of the Ministry of Justice, Tirana 1931 p. 28

Statovci, Ejup. The Property Legal Relations in Real Estates in the ASP of Kossovo, Prishtina 2009 p. 27

Meta, B. Albanian Monarchy 1928-1939. Albanological Study Center, The Institute of History, Tirana 2011, p. 45

The Right to Servitudes, Comparative Aspects, Tirana 2009.

Property protection, comparative studies, Prishtina 2009.

Statovci, Ejup The Ownership Origin and Development, Comparative Study, Prishtina 2009 p. 15,245,272,312,337.

Gjata, Rustem. Civil Law Things and Ownership, Tirana 2011 p. 45

Galgano, Francesco. The Private Law, Luarasi 2006 p.141

Nuni, Ardian. Business Law. Tirana 2006 p.24,422

Shehu, Avni. Ownership. Albin, Tirana 2000 p.2

Hetemi, Mehdi. Some current topics of Market Economy. Prishtina 2005.

Basic knowledge of Business Law, Prishtina 2006, p. 179,180

Feti Gjilani, Fundamentals of Civil Law in the People's Republic of Albania, Tirana 1974.

Arta Mandro, The Roman Law, Tirana 2006

Andrea Nathanaili, Property Rights in PRA, course of lectures in the Law Faculty of the University of Tirana, Tirana 1974 p. 3

Paskal Haxhi, Juridical Regime for Land in Albania, Albin, Tiranë, 2002.

Andrija Gams, Fundamentals of Private Law. Prishtina 1966 p. 32

Private Property in Albania, Tirana

Civil Code of the Republic of Albania, September 2005.

Civil Code of the year 1929. Publication of the Ministry of Justice, Tirana 2010, p. 279 